\title{
パパイア軸腐病（新称）とその病原菌
}

\section{矢口行雄*・中村重正 $*$}

Yukio YAGUCHI and Shigemasa NAKAmURA:

Stem-end Rot of Papaya and Its Pathogens

\begin{abstract}
Unknown rots in stem-end of papaya fruit imported in 1986 to 1987 were occurred in Japan. The symptoms were classified into five types. The causal fungi were identified as Botryodiplodia theobromae, Phomopsis sp., Colletotrichum gloeosporioides, Fusarium solani, and Ascochyta caricae on the basis of the morphological characteristics and the pathogenicity on the stem-end of papaya fruit.
\end{abstract}

(Received May 16, 1991)

Key words : stem end rot of papaya, Botryodiplodia theobromae, Phomopsis sp., Colletotrichum gloeosporioides, Fusarium solani, Ascochyta caricae.

\section{緒 言}

近年，パパイアの輸入量の増加に伴い，輸送中ある いは市場における果実の腐敗が問題となっている。こ の実態を明らかにするため, 輸入果実の腐敗状況を調 查するとともに, 病徵, 病原菌の分離ならびに病原性 を検討した結果，果実全面が腐敗する実腐れ（fruit surface rot) より果梗切断面が腐敗する軸腐れ (stemend rot）の発生が多かった。軸部の腐敗に関与する病 原菌として, Botryodiplodia theobromae, Phomopsis sp., Colletotrichum gloeosporioides, Fusarium solani, Ascochyta caricae を確認したので報告する。本報告の 概要は,すでに植物病理学会で講演発表した ${ }^{17,18)}$ 。

\section{材料および方法}

輸入果実の腐敗 1986 年 9 月から 1987 年 5 月にわ たって, 東京国際空港で通関したハワイ産パパイア(品 種：ソロ種）から任意に抽出した 157,783 個の果実の 腐敗状況を調査し, 症状別に病原菌の種類を同定した。

病原菌の分離および接種試験 パパイアの軸部の腐 敗部位から胞子塊または組織片を採取して PDA 培地

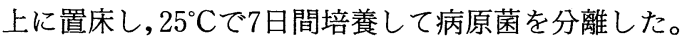
供試菌として病徵の異なる部位より得た 5 分離株 PB-1, PP-1, PC-1, PF-1, PA-1 の直径 4 mm の培養
菌叢片を用い, 表面殺菌したパパイア $1 / 4$ 熟果 (果実の 1/4 が黄化）の軸部および果実表面に有傷あるいは無 傷接種した後, 経時的に腐敗状況を観察し, 下記に示 すように腐敗程度によって 0 ～ 4 の指数を与え, 平均腐 敗度を求めた。

腐敗指数： 0 ，腐敗なし；1，わずかに軟化し，菌系 の発生が認められる; 2 , 菌系が発生し軟化, 腐敗が拡 がる；3, 腐敗部位が拡大し, 分生子殼または分生子層 の形成が始まる； 4 腐敗が果実の $1 / 3$ 以上に拡大し胞 子形成が認められる。

$$
\text { 平均腐敗度 }=\frac{0 \times \text { 果数 }+\cdots \cdots+4 \times \text { 果数 }}{\text { 総果数 }}
$$

結果

\section{輸入果実の腐敗状況および病徵}

通関直後に輸入果実の腐敗を調查した結果，軸部の 腐敗の発生率は $0.76 \%$ で果実表面の腐敗果発生率 $0.15 \%$ に比べて著しく高かった（Table 1)。さらに軸 部の腐敗は外観から次の 5 タイプに類別された。

タイプ I：果梗中心部から軟化が始まり，急速に周 辺に腐敗が拡がり，4５日後には黒色に腐敗し，その 上に黒色，球形の分生子殼を豊富に形成する。分生子 殼は成熟すると，その頂部から白色および黒緑色の分 生子を連鎖状に吐出し, 湿度が高いと, 灰色, ビロー

\footnotetext{
* 東京農業大学農学部 Faculty of Agriculture, Tokyo University of Agriculture, Setagaya-ku, Tokyo 156, Japan
} 
Table 1. Occurrence of five types of stem-end rots on papaya fruits imported in 1986-1987

\begin{tabular}{|c|c|c|c|c|c|c|c|}
\hline \multirow{2}{*}{ Month } & \multirow{2}{*}{$\begin{array}{l}\text { Total No. } \\
\text { of fruits }\end{array}$} & \multicolumn{6}{|c|}{ Rotted types $^{a)}$} \\
\hline & & Total (\%) & Type I & Type II & Type III & Type IV & Type V \\
\hline Sep. & 14,121 & $\begin{array}{c}108 \\
(0.8)\end{array}$ & 81 & 6 & 11 & 10 & 0 \\
\hline Oct. & 20,707 & $\begin{array}{c}434 \\
(2.1)\end{array}$ & 237 & 84 & 77 & 23 & 13 \\
\hline Nov. & 21,308 & $\begin{array}{c}195 \\
(0.9)\end{array}$ & 97 & 36 & 24 & 33 & 5 \\
\hline Dec. & 24,903 & $\begin{array}{c}202 \\
(0.8)\end{array}$ & 88 & 43 & 46 & 19 & 6 \\
\hline Jan. & 11,098 & $\begin{array}{c}106 \\
(1.0)\end{array}$ & 55 & 36 & 10 & 4 & 1 \\
\hline Feb. & 14,234 & $\begin{array}{c}70 \\
(0.5)\end{array}$ & 22 & 23 & 17 & 4 & 4 \\
\hline Mar. & 18,307 & $\begin{array}{r}52 \\
(0.3)\end{array}$ & 21 & 17 & 10 & 4 & 1 \\
\hline Apr. & 21,864 & $\begin{array}{c}6 \\
(0.03)\end{array}$ & 5 & 1 . & 0 & 0 & 0 \\
\hline May & 11,241 & $\begin{array}{c}31 \\
(0.3)\end{array}$ & 14 & 10 & 7 & 0 & 0 \\
\hline Total & 157,783 & $\begin{array}{l}1,205 \\
(0.76)\end{array}$ & $\begin{array}{c}620 \\
(0.39)\end{array}$ & $\begin{array}{l}256 \\
(0.16)\end{array}$ & $\begin{array}{l}202 \\
(0.13)\end{array}$ & $\begin{array}{c}97 \\
(0.06)\end{array}$ & $\begin{array}{c}30 \\
(0.02)\end{array}$ \\
\hline
\end{tabular}

a) Symptoms of stem-end rots ; Type I : Water-soaked marginally at first, then formed lesions with discoloration to black, and finally roughened the surface with erumpent pycnidia. Type II : Wrinkles first, then became translucent and yellow to brown. Type III : Water-soaked first, then formed lesions with light brown margins and light orange spore masses. Type IV : Developed dry lesions covered by a white, rather compact mycelial mat. Type V : Formed black lesions with a wrinkled surface and scattered pycnidia embedded in the tissue.

ド状の気中菌系を密生する（Plate I-1）。

タイプII：はじめ軸部が水浸状に軟化し，腐敗が周 辺に拡がる。病状が進むと, 黒色, 球状の分生子殼を 形成し，その頂部より分生子を連鎖状に吐出する。夕 イプIによる腐敗に類似するが, 腐敗部は淡色で象皮 状になるので区別できる（Plate I-2）。

タイプIII：はじめ軸部が軟化し, 水浸斑が周辺に拡 がって暗褐色となり，その上に橙色の分生子層を密生 する (Plate I-3)。

タイプIV：軸部には白色の菌糸が密生し, 周辺に水 浸斑が認められるが, 腐敗の進展は遅く, 乾腐状とな るのが特徴である（Plate I-4）。

タイプV：はじめ軸部は水浸状となり, 腐敗はしだ いに拡がって黒色になり，表皮下に分生子殼を形成す る。本菌による腐敗は夕イプIIに類似するが, 腐敗が 進むと黒色になる点で区別できる（Plate I-5）。

腐敗のタイプ別発病を調査した結果, 調査期間を通 じてタイプ I が $0.39 \%$ で最も発生率が高く, 次いで夕 イプII $0.16 \%$, タイプIII $0.13 \%$, タイプIV $0.06 \%$, 夕 イプV 0.02\%であった。パパイアは通年輸入されてい るが; 今回の調査期間については, 腐敗の発生が 10 月
から翌年 2 月に多くみられた (Table 1$) 。$

\section{病原菌の分離おょび病原性}

各タイプ別に腐敗部位より常法によって得た PB-1, PP-1, PC-1, PF-1, PA-1の 5 分離株をパパイア $1 / 4$ 熟 果の軸部に接種した結果，いずれの分離株も果実の軸 部を強く腐敗させ, 自然発病と同様な病徵を示した (Table 2)。分離株 PP-1, PC-1, PA-1 は接種 2 日目で 接種部位を軟化し始め, 5 日目には分生子殼あるいは 分生子層を形成し， 7 日目で果実の $1 / 3$ 以上を腐敗さ せ，分生子を形成した。これらの分離株に比べ PB-1 は, 接種 5 日目で果実の $1 / 3$ 以上を腐敗させ, 分生子を 形成し, 腐敗が著しく早かった。また分離株 PF-1によ る腐敗は, 接種 2 日目では全く変化がみられず, 他の 4 菌株に比べて初期のうち腐敗の進行が遅い傾向を示し たが，接種 7 日目には他の 4 菌株と同様に果実の $1 / 3$ 以上に腐敗が拡がった。

また果実表面に対し全分離株とも有傷, 無傷の果実 を腐敗させたが, 腐敗の進展は軸部接種に比べて遅か った (Table 3)。5 分離株の中では, 分離株 PC-1 が果 実表面に対し最も病原性が強く, 腐敗果率は有傷 73\%，無傷 33\%であった。 


\section{病原菌の形態および同定}

軸部に接種した腐敗部より，各タイプ別の病原菌の 形態について調査した結果は以下のとおりであった。

タイプ I の病原菌：分生子殼は黒色, 球形, 大きさ 140～260 $\mu \mathrm{m}$ 。殼壁は 2 層よりなり, 頂部に孔口を有す る(Plate II-1)。分生子は無色, 広楕円形, 単胞, 大き さ $20 \sim 30 \times 14 \sim 16.4 \mu \mathrm{m}$ (平均 $25.6 \times 14.4 \mu \mathrm{m}$ ) で, 孔口より吐出後, 暗褐色, 広楕円形で 2 胞となり, 大き さ20 27.2 $\times 12 \sim 15.9 \mu \mathrm{m}$ (平均 $24.9 \times 13.3 \mu \mathrm{m}$ ) (Plate II-2)。分離株 (PB-1，2，3，4）は, PDA 培地 上で明所培養により 3〜 5 日目に分生子殼と分生子を 形成した。以上の形態的特徵から, 本菌はBotryodiplodia theobromae Patouillard (Syn. Lasiodiplodia theobromae Pat.) ${ }^{10)}$ と同定された。

タイプIIの病原菌：分生子殼は黒色, 球形〜不整形, 大きさ $150 \sim 400 \mu \mathrm{m}$ 。殼壁の外部は厚膜細胞よりな り，頂部に孔口を有する(Plate II-3)。分生子は 2 型あ り, A 型分生子は紡鍾形 楕円形, 2 顆粒を含み, 大き 巳 $5.4 \sim 7.7 \times 1.8 \sim 2.7 \mu \mathrm{m}$ (平均 $6.2 \times 2.2 \mu \mathrm{m}$ )。B 型 分生子は糸状, 屈曲, 大きさ $12.8 \sim 20.5 \times 0.7 \sim 1.2$ $\mu \mathrm{m}$ (平均 $17.4 \times 0.9 \mu \mathrm{m}$ ) である（Plate II-4）。以上 の形態的特徵から, 本菌は Phomopsis 属に所属する が，種名についてはさらに検討を要する。

タイプIII病原菌：分生子層がはじめ表皮下に形成 され，成熟すると表皮を裂開して露出する。分生子柄 は無色, 単胞, 分生子は, 無色, 長棈円形, やや弯曲 し, 大きさ $14.1 \sim 19.7 \times 3.6 \sim 5.4 \mu \mathrm{m}$ (平均 $16.7 \times 4.9$ $\mu \mathrm{m}$ ) である（Plate II-5，6)。分離菌（PC-1，2，3， 4，5）は, PDA 培地上で, 橙色, 綿毛状で, 分生子を 形成した。いずれも完全時代は認められなかった。以 上の形態的特徵から, 本菌は Colletotrichum gloeosporioides (Penzig) Penzig et Saccardo ${ }^{1,14}$ と同 定された。

タイプIVの病原菌：腐敗部では小型分生子のみを集 塊状に形成し, 分離株 (PF-1，2，3) は PDA 培地上で は長い分生子柄が菌糸から側生し, その先端に無色, 棈円形，大きさ $7.5 \sim 16.4 \times 3 \sim 5.9 \mu \mathrm{m}$ (平均 $13.8 \times$ $4.3 \mu \mathrm{m}$ ) の小型分生子を形成する（Plate II-7）。果実 上では大型分生子は認められなかったが，カーネーシ

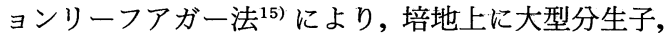
無色, 三日月形, 3 5 隔膜を有する。大型分生子の大 きさは, 5 隔膜分生子 : $30 \sim 38 \times 3 \sim 4 \mu \mathrm{m}$ (平均 $36 \times 4$ $\mu \mathrm{m}$ ), 4 隔膜分生子 : $28 \sim 36 \times 3 \sim 4 \mu \mathrm{m}$ (平均 $31 \times 3 \mu \mathrm{m}$ ),

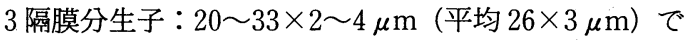
ある (Plate II-8)。以上の形態的特徵から, 本菌は Fusarium solani (Martius) Saccardo ${ }^{3)}$ と同定された。

タイプVの病原菌：分生子殼は黒色, 球形, 大きさ 104 208 $\mu \mathrm{m}$, 頂部に孔口を有する(Plate II-9)。分生 子は, 無色, 楕円形, 大きさ $6 \sim 10 \times 2 \sim 4 \mu \mathrm{m}$ (平均 $7.7 \times 2.7 \mu \mathrm{m})$ (Plate II-10)。分離株（PA-1，2）は, PDA 培地, 明所培養により 6〜7 日目に分生子殼が認 められ分生子を形成した。以上の形態的特徵から, 本 菌は Ascochyta caricae Patouillard ${ }^{4)}$ と同定された。

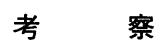

パパイア果実の腐敗については,アメリカ2,6,8), イギ リス ${ }^{5)}$ インド13) など世界中の産地ならびに消費地で 問題となっている。ハワイ産のパパイアは，アメリカ 本土向けに船舶および航空輸送で行っているが, 腐敗 果の発生は船舶輸送で 10〜 40\%, 航空輸送で 5 30\% であったと報告されている2）本調查の結果，わが国に 航空輸送されたハワイ産のパパイアの腐敗の発生は

Table 2. Pathogenicity of five fungal isolates on stem-end of papaya ${ }^{a)}$

\begin{tabular}{|c|c|c|c|c|c|c|}
\hline \multirow{2}{*}{$\begin{array}{l}\text { Rotted type } \\
\text { (Isolate) }\end{array}$} & \multirow{2}{*}{ Pathogen } & \multirow{2}{*}{$\begin{array}{c}\text { No. of } \\
\text { inoculated } \\
\text { fruits }\end{array}$} & \multirow{2}{*}{$\begin{array}{c}\text { Rate of } \\
\text { diseased } \\
\text { fruits (\%) }\end{array}$} & \multicolumn{3}{|c|}{ Disease development } \\
\hline & & & & 2 & 5 & 7 (days) \\
\hline $\begin{array}{l}\text { Type I } \\
\text { (PB-1) }\end{array}$ & B. theobromae & 10 & 100 & $\begin{array}{c}0.6^{\mathrm{b})} \\
(0-2)\end{array}$ & $\begin{array}{c}3.4 \\
(3-4)\end{array}$ & $\begin{array}{c}3.9 \\
(3-4)\end{array}$ \\
\hline $\begin{array}{l}\text { Type II } \\
\text { (PP-1) }\end{array}$ & Phomopsis sp. & 10 & 100 & $\begin{array}{c}0.3 \\
(0-1)\end{array}$ & $\begin{array}{r}1.6 \\
(0-3)\end{array}$ & $\begin{array}{l}3.7 \\
(3-4)\end{array}$ \\
\hline $\begin{array}{l}\text { Type III } \\
\text { (PC-1) }\end{array}$ & C. gloeosporioides & 10 & 100 & $\begin{array}{c}0.6 \\
(0-2)\end{array}$ & $\begin{array}{c}1.0 \\
(0-2)\end{array}$ & $\begin{array}{c}2.9 \\
(2-4)\end{array}$ \\
\hline $\begin{array}{l}\text { Type IV } \\
\text { (PF-1) }\end{array}$ & F. solani & 10 & 100 & $\begin{array}{c}0 \\
(0)\end{array}$ & $\begin{array}{c}0.9 \\
(0-2)\end{array}$ & $\begin{array}{c}2.0 \\
(1-4)\end{array}$ \\
\hline $\begin{array}{l}\text { Type V } \\
\text { (PA-1) }\end{array}$ & A. caricae & 20 & 100 & $\begin{array}{c}0.1 \\
(0-1)\end{array}$ & $\begin{array}{c}1.8 \\
(0-3)\end{array}$ & $\begin{array}{c}3.0 \\
(2-4)\end{array}$ \\
\hline
\end{tabular}

a) Inoculated by placing mycelial agar discs $(4 \mathrm{~mm}$ diam.) on the stem-end of papaya fruits.

b) Average of rot index with its range. 
Table 3. Pathogenicity of five fungal isolates on fruit surface of papaya ${ }^{a)}$

\begin{tabular}{|c|c|c|c|c|c|c|c|}
\hline \multirow{2}{*}{$\begin{array}{c}\text { Rotted type } \\
\text { (Isolate) }\end{array}$} & \multirow{2}{*}{ Pathogen } & \multirow{2}{*}{ Inoculate } & \multirow{2}{*}{$\begin{array}{c}\text { No. of } \\
\text { inoculated } \\
\text { fruits }\end{array}$} & \multirow{2}{*}{$\begin{array}{c}\text { Rate of } \\
\text { diseased } \\
\text { fruits (\%) }\end{array}$} & \multicolumn{3}{|c|}{ Disease development } \\
\hline & & & & & 2 & 5 & 7 (days) \\
\hline \multirow{4}{*}{$\begin{array}{l}\text { Type I } \\
(\mathrm{PB}-1)\end{array}$} & \multirow[t]{4}{*}{ B. theobromae } & Wound & 15 & 47 & $0^{\text {b) }}$ & 0.5 & 0.9 \\
\hline & & & & & $(0)$ & $(0-1)$ & $(0-2)$ \\
\hline & & Unwound & 15 & 33 & 0 & 0 & 0.7 \\
\hline & & & & & $(0)$ & $(0)$ & $(0-2)$ \\
\hline \multirow{4}{*}{$\begin{array}{l}\text { Type II } \\
(\mathrm{PP}-1)\end{array}$} & \multirow[t]{4}{*}{ Phomopsis sp. } & Wound & 15 & 60 & 0 & 0.7 & 1.5 \\
\hline & & & & & $(0)$ & $(0-3)$ & $(3-4)$ \\
\hline & & Unwound & 15 & 20 & 0 & 0.2 & 0.3 \\
\hline & & & & & $(0)$ & $(0-3)$ & $(0-3)$ \\
\hline \multirow{4}{*}{$\begin{array}{l}\text { Type III } \\
\text { (PC-1) }\end{array}$} & \multirow[t]{4}{*}{ C. gloeosporioides } & Wound & 15 & 73 & 0 & 1.1 & 1.9 \\
\hline & & & & & $(0)$ & $(0-3)$ & $(0-4)$ \\
\hline & & Unwound & 15 & 33 & 0 & 0.2 & 0.7 \\
\hline & & & & & $(0)$ & $(0-2)$ & $(0.4)$ \\
\hline \multirow{4}{*}{$\begin{array}{l}\text { Type IV } \\
(\mathrm{PF}-1)\end{array}$} & \multirow[t]{4}{*}{ F. solani } & Wound & 15 & 23 & 0 & 0.4 & 0.9 \\
\hline & & & & & $(0)$ & $(0-1)$ & $(0-3)$ \\
\hline & & Unwound & 15 & 13 & 0 & 0.1 & 0.2 \\
\hline & & . & & & $(0)$ & $(0-1)$ & $(0-2)$ \\
\hline \multirow{4}{*}{$\begin{array}{l}\text { Type V } \\
\text { (PA-1) }\end{array}$} & \multirow[t]{4}{*}{ A. caricae } & Wound & 30 & 27 & 0 & 0.7 & 0.9 \\
\hline & & & & & $(0)$ & $(0-3)$ & $(0-4)$ \\
\hline & & Unwound & 30 & 17 & 0 & 0.1 & 0.3 \\
\hline & & & & & $(0)$ & $(0-3)$ & $(0-4)$ \\
\hline
\end{tabular}

a) Inoculated by placing mycelial agar discs ( $4 \mathrm{~mm}$ diam.) on the fruit surface of papaya.

b) Average of rot index with its range.

0.91\%で，これはアメリカ本土向けに比べるとかなり 低い值であった。

ハワイでは, パパイアの Fruit surface rot の病原菌 として, C. gloeosporioides, Mycosphaerella sp., Phomopsis sp., Alternaria alternata (Fr.) Keissler, Stemphylium lycopersici Yamamoto, $F$. solani, Guignardia sp., Stem-end rotの病原菌としては, Ascochyta caricae, Botryodiplodia theobromae, Phomopsis sp., F. solani, Alternaria alternata, S. lycopersici, C. gloeosporioides, Mycosphaerella sp. など が報告されているが2,6,8)，わが国ではわずかに炭そ病 菌 Glomerella cingulata (Stoneman) Spaulding et Schrenk による輸入果実の腐敗が報告されているに 過ぎない9)。今回, 空輸されたパパイアの通関直後に行 った調査では, 果実軸部の腐敗が目立っていた。

軸腐れの初期症状およびその進展, 子実体の形成な ぞから腐敗の状態を 5 タイプに分け，それぞれの病徴 を記載するとともに, 各タイプに関与する病原菌とし て, B. theobromae, Phomopsis sp., C. gloeosporioides, F. solani, A. caricae を同定した。これらの病原菌のう ち, B. theobromaeによる腐敗は最も著しかった。本種 は熱帯から亜熱帯などに分布し，パパイアのほかバナ ナ,マンゴーを侵す多犯性菌で19), わが国でははじめ台
湾産バナナの黒腐病菌として報告された ${ }^{7)}$ 。近年, 徳島 県では栽培ナシのボトリオディプロディア枝枯病 ${ }^{16)}$, 東京都小笠原諸島ではインドゴムノキ枝枯病 ${ }^{12)}$, 千葉 県ではヒメツルニチニチソウ茎枯病 ${ }^{11)}$ の病原菌とし て国内における分布が報告されている。

Phomopsis sp. による腐敗は, 進展が早く, 黒変せず 淡色で象皮状になるのが特徴である。ハワイではパパ イアの Stem-end rotの主要な病原菌として報告され ている ${ }^{2,6)}$ 。

C. gloeosporioides による腐敗は, 橙色の分生子層を 密生するのが特徴である。本菌は, すでにパパイア炭 そ病菌として知られているが, 今回, 本菌による軸部の 腐敗が多く認められたので, 他の 4 病原菌とともにパ パイア軸腐病菌に関与する病原菌として提案したい。

F. solaniによる腐敗は, 比較的に進展が遅く, 乾腐 するのが特徴であり, 他の病原菌による腐敗と区別が 容易であった。

A. caricaeによる腐敗の発生は, 今回の調査では最 も少なかったが, 病原性は他の 4 種と同様に強く, また ハワイ ${ }^{2)}$,インド13) では本種による fruit surface rot が 問題になっている。

わが国では軸部の腐敗はまだ報告がないが, 諸外国 では上述のように, stem-end rot が知られ, その関与 
する病原菌が知られている。今回明らかになった軸部 の腐敗には 5 タイプが認められたが, 病名はいずれも 軸腐病 (stem-end rot) と呼称することを提案し, 病原 菌として Botryodiplodia theobromae, Phomopsis sp., Colletotrichum gloeosporioides, Fusarium solani, Ascochyta caricae の 5 種を列記する。

\section{摘 要}

輸入パパイアの腐敗を 1986 年から 1987 年に調查し
た結果,わが国では未報告の軸部の腐敗が認められた。 その病徴は 5 タイプに類別され, 病原菌の形態的特徵 および接種試験の結果，パパイアの軸部の腐敗に関与 する病原菌として Botryodiplodia theobromae, Phomopsis sp., Colletotrichum gloeosporioides, Fusarium solani, Ascochyta caricae を同定した。この病名 をパパイア軸腐病 (stem-end rot) と呼称することを提 案した。

\section{引用文献}

1. Aa, H.A. Van der, Noordeloos, M.E. and Gruyter, J. de (1990). Species concepts in some larger genera of the Coelomycetes. Studies in Mycology (Bearn) 32:3-19.

2. Alvarez, A.M. and Nishijima, W.T. (1987). Postharvest diseases of papaya. Plant Dis. 71:681-686.

3. Booth, C. (1971). The Genus Fusarium. Commonwealth Mycological Institute. pp. 237.

4. Chowdhu, S. (1950). A fruit rot of papaya (Carica papaya L.) caused by Ascochyta caricae Pat. Trans. Br. Mycol. Soc. $33: 317-322$

5. DA Costa, E.W.B. (1944). Disease of the papaya. Queensland Agricultural J. $58: 282-293$.

6. Hine, R.B. (1965). Disease of papaya (Carica papaya L.) in Hawaii. Hawaii Agric. Exp. Stn. Univ. Hawaii 136 : 5-26.

7. 平井篤造 (1938)。台湾産甘蕉の輸送中に打ける病害. 日植病報 $8: 145-166$.

8. Hunter, J.E. (1972). Incidence, epidemiology and control of fruit diseases of papaya in Hawaii. Trop. Agric. (Trinidad) $49: 61-71$

9. 中村重正・小野里敏美・木村 智 (1979)。熱帯果樹の炭疽病に関する研究 第 1 報 各種果実に対する分離系の病原 性について。目植病報 45：545（講要）。

10. Patouillard, N. and Lagerheim, G. (1971). Champignons de lequateur. Bull. de la Soc. Mycol. de France $8: 136$.

11. 酒井 宏・長尾英幸・平野和弥・雨宮良幹 (1990)。 ヒメッルニチニチソウの茎枯病の病原菌について。 日植病報 56 ： 149 (講要).

12. 佐藤豊三 (1990)。Lasiodiplodia theobromaeによる小笠原産熱帯作物の病害. 日植病報 $56: 388$ (講要).

13. Srivastava, M.P. and Tandon, R.N. (1971). Post-harvest diseases of papaya. PANS. $17: 51-54$.

14. Sutton, B.C. (1980). The Coelomycetes. Commonwealth Mycological Institute. pp. 530.

15. Toussoun, T.A. and Nelson, P.E. (1976). A pictorial guide to the identification of Fusarium species, 2nd. Ed., Penn. State Univ. Press. pp. 10.

16. 大和浩国 (1983)。 ナシのボトリオディプロディア枝枯病について．日植病報 $49: 401$ (講要).

17. 矢口行雄・中村重正 (1987)。パパイア軸腐病（新称）について。 日植病報 $53: 378$ (講要).

18. 矢口行雄・中村重正 (1987)。 パパイア軸腐病(2)。日植病報 $54: 126$ (講要)。

19. 矢口行雄・西原泰次・大和浩国・中村重正 (1990)。 パパイア軸腐病 (4) 各種植物より分離した Botryodiplodia theobromae の果実に対する病原性の比較. 日植病報 $56: 374$ (講要).

\section{Explanation of plates}

\section{Plate I}

Symptoms of stem-end rots of papaya caused by: 1, B. theobromae ;2, Phomopsis sp. ; 3, C. gloeosporioides ; 4, F. solani ; 5 , A. caricae.

\section{Plate II}

Morphology of B. theobromae, Phomopsis sp., C. gloeosporioides, F. solani, and A. caricae.

1. Pycnidium of $B$. theobromae.

2. Aseptate and septate conidia of $B$. theobromae.

3. Pycnidium of Phomopsis sp.

4. A- and B-conidia of Phomopsis sp.

5. Acervulus of $C$. gloeosporioides.

6. Conidia of $C$. gloeosporioides.

7: Microconidia and conidiophore of $F$. solani.

8. Macroconidia of $F$. solani.

9. Pycnidium of $A$. caricae.

10. Conidia of $A$. caricae. 


\section{Plate I}
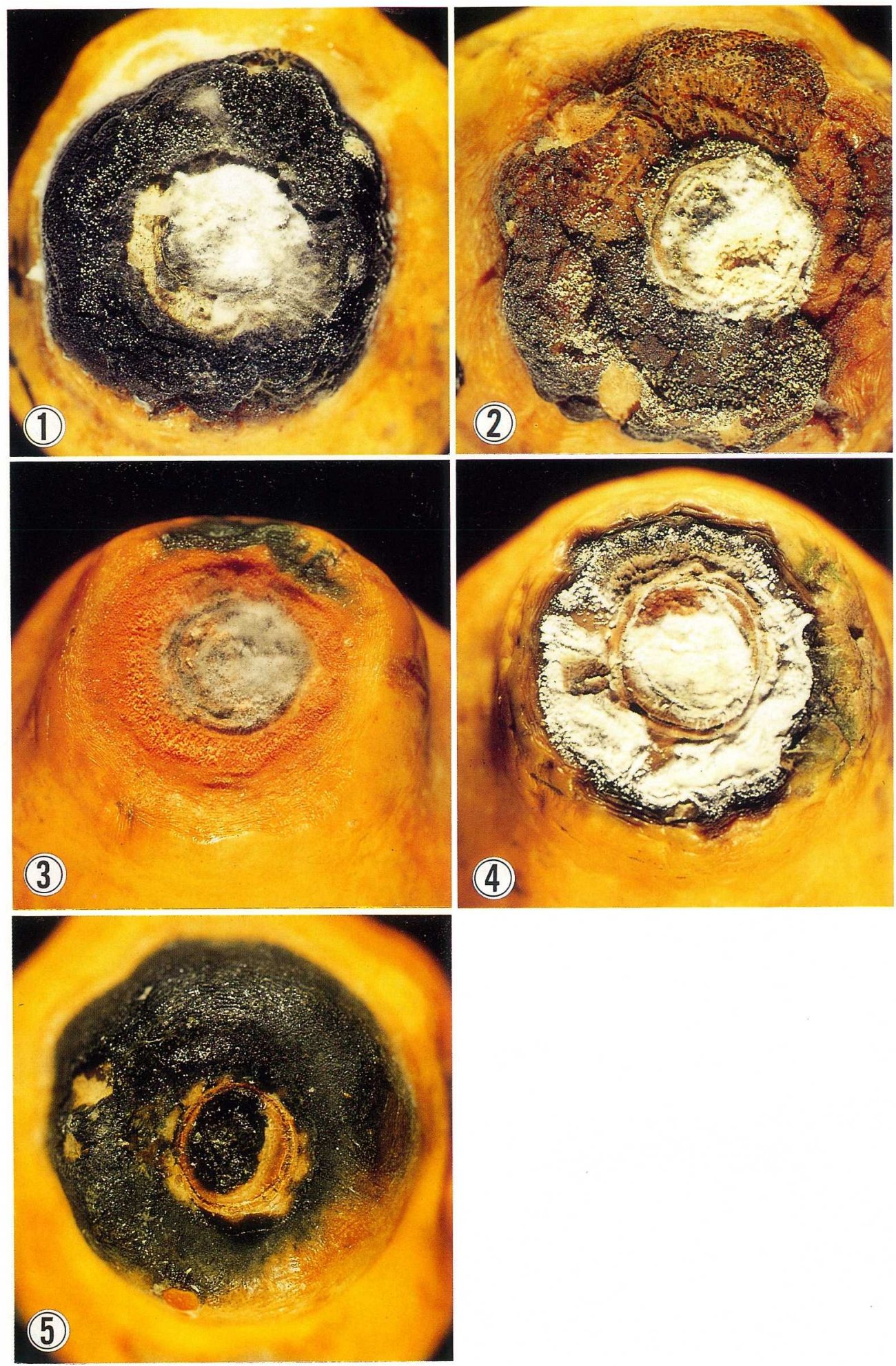


\section{Plate II}
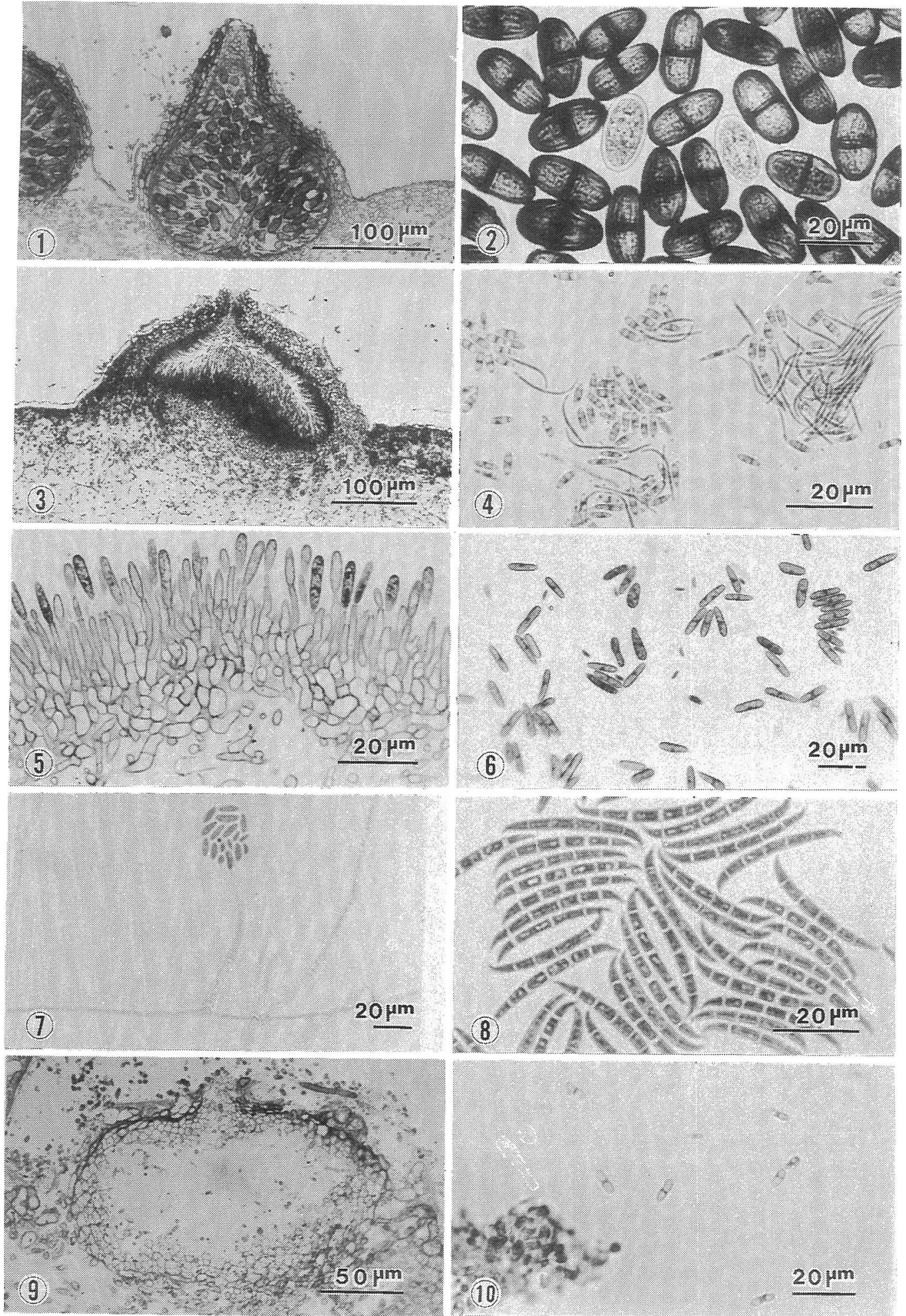

$20 \mu \mathrm{m}$

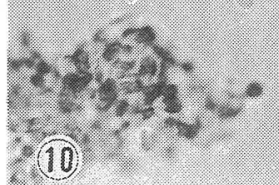

